\title{
Attorneys' Fees in Class Actions Governed by Fee-Shifting Statutes
}

\author{
Martha Pacold $\dagger$
}

Calculating the ideal compensation for plaintiffs' attorneys in class actions is difficult. When plaintiffs bring suit individually (rather than as members of a class), they usually set their attorneys' fees by contract before the attorneys provide any services.' In contrast, it is impossible for a plaintiff class to contract with its attorneys before filing suit. ${ }^{2}$ This is because a class cannot be certified, and therefore cannot exist, until after suit is filed ${ }^{3}$ through the initiative of entrepreneurial attorneys. Thus, attorneys' fees in class actions are inevitably set by the court after settlement or trial rather than before the case begins.' Frequently, plaintiffs' attorneys are compensated for their time, effort, and risk out of a "common fund" created for the benefit of the class.

After settlement or judgment in the class's favor, several considerations militate in favor of compensating the attorneys generously, including the effective enforcement of laws, the work necessary to overcome the low incentives for any of the numerous class members to sue individually, and the substantial uncertainty of success.' But

$\dagger$ B.A. 1999, Indiana University; J.D. Candidate 2002, The University of Chicago.

1 See Janet Cooper Alexander, Contingent Fees and Class Actions, 47 DePaul L Rev 347, 347-48 (1998) (distinguishing method of compensation in class actions from individual contingent fee cases).

2 See id at 348.

3 See FRCP 23 (FRCP 23(c)(1) directs: “As soon as practicable after the commencement of an action brought as a class action, the court shall determine by order whether it is to be so maintained.").

4 See Alexander, 47 DePaul L Rev at 348 (cited in note 1) (noting that in class actions "entrepreneurial lawyers bring the case and the class into being on the prospect of an eventual fee based on a large aggregate recovery").

5 One commentator summarizes the pivotal role of class counsel as follows:

In a typical class action, a law firm will (1) craft a potential cause of action ... (2) move to define and certify a class of injured plaintiffs, (3) petition a court for approval to represent the class, and (4) prosecute the case through settlement or trial. Every step of this laborintensive process will have been undertaken with no explicit advance agreement with anyone about what the terms of attorney compensation are to be. Those terms are generally defined only after the fact by the court.

William J. Lynk, The Courts and the Plaintiffs' Bar: Awarding the Attorney's Fee in Class-Action Litigation, 23 J Legal Stud 185, 185 (1994).

6 See Part II.B.

7 See, for example, Amchem Products, Inc $v$ Windsor, 521 US 591, 617 (1997) (stating that "[t]he policy at the very core of the class action mechanism is to overcome the problem that 
equally important factors line up on the other side. For example, the absence of many of the plaintiffs from the litigation means that, without control by the court, the attorneys can easily act in their own financial interests rather than those of their clients. ${ }^{8}$ Given these competing considerations, setting the right attorneys' fees is bound to be complex in any class action.

But the problem becomes even thornier in a "hybrid" class action-a class action initiated under a statute that has a fee-shifting provision. Statutory fee-shifting provisions allow courts to order losing parties to pay the prevailing parties' attorneys' fees. ${ }^{10}$ The method courts normally use to calculate fees under such statutes differs from the prevailing method for calculating fees in simple class actions. ${ }^{11} \mathrm{Be}-$ cause of the differences between these methods, statutory fees can fall far short of fees in simple class actions.

If there were no way to avoid the lower statutory fee, plaintiffs' attorneys might stop bringing hybrid class actions altogether; they would bring class actions only under statutes that lack fee-shifting provisions. But there is sometimes a way to circumvent these statutes: settlement. Since many fee-shifting provisions are activated only after one party "prevails," fees according to simple class action fee principles rather than under the statute. ${ }^{13}$ The result is an enormous incentive for plaintiffs' attorneys in hybrid class actions to settle, possibly at the expense of their dispersed, and often unknown, clients. Since the fee structure makes plaintiffs' attorneys prefer settlement rather than trial, they presuma-

small recoveries do not provide the incentive for any individual to bring a solo action prosecuting his or her rights. A class action solves this problem by aggregating the relatively paltry potential recoveries into something worth someone's (usually an attorney's) labor."), quoting Mace $v$ Van Ru Credit Corp, 109 F3d 338, 344 (7th Cir 1997).

Scholars have described the class action procedure's objectives as follows:

The class action procedure serves a number of objectives: It conserves social resources by consolidating many similar cases in a single proceeding, enables persons with small claims to obtain a hearing on their grievances that would otherwise not be economically feasible, and facilitates compensation for large numbers of injured persons. Class actions also serve deterrent purposes.

Geoffrey P. Miller and Lori S. Singer, Nonpecuniary Class Action Settlements, 60 L \& Contemp Probs 97, 98 (Autumn 1997).

8 See Miller and Singer, $60 \mathrm{~L} \&$ Contemp Probs at 98 (cited in note 7) (stating that "critics of the process charge that class suits often take the form of meritless nuisance litigation filed solely to obtain a settlement offer, and that such suits are brought by plaintiffs attorneys whose primary motive is to settle the case for a high fee, even at the class's expense").

9 In this Comment, a "hybrid" class action is a class action initiated under a statute with a fee-shifting provision but that settles or reaches judgment, creating a common fund.

10 See Part I.A for an explanation of statutory fee shifting.

11 See Part II for a discussion of the methods of fee calculation.

12 See Part I.A.

13 See Part I.A.2. 
bly settle valuable cases for a lower amount per plaintiff than they would demand if they tried the cases. ${ }^{14}$

Plaintiff classes' attorneys already have a huge incentive to settle because trying a class action requires tremendous resources. ${ }^{15}$ In fact, from society's perspective, settlement can sometimes be more favorable than trial because the resources of the judicial system are limited. $^{16}$ However, the expected recovery for the plaintiffs, rather than the expected compensation of their attorneys, should be the determinative factor in the decision between settlement and trial. The current rules for setting fees in hybrid cases create incentives for plaintiffs' attorneys that are too heavily tilted toward settlement. This bias will lower recoveries for plaintiff classes.

This Comment proposes that the rules for setting fees in hybrid cases should better align the incentives of plaintiffs' attorneys with those of their clients. Courts should presume that the reasonable fee for a successful plaintiffs' attorney in a hybrid case is the fee that would have been set in a simple class action, and that the statutory fee establishes a minimum but not a maximum amount..$^{17}$ If this presumption is established, attorneys will still be inclined to settle to avoid expending vast resources at trial. But at least they will not settle solely because the fee-shifting statutes make settlement more lucrative than winning a large judgment for the class.

Part I explains statutory fee shifting and the common fund doctrine-the two exceptions to the usual rule for paying attorneys in America that combine in hybrid class actions. Part II describes the lodestar and the percentage methods of calculating fees, which correspond roughly to statutory fee-shifting and the common fund doctrine. Part III explains how problems arise when the two methods combine in hybrid cases. Part IV proposes the solution: a presumption that the percentage method establishes a reasonable minimum fee.

\section{EXCEPTIONS TO THE AMERICAN RULE}

Under the "English Rule," followed in the civil courts of many countries, a prevailing litigant is entitled to recover attorneys' fees from her opponent. ${ }^{18}$ In contrast, the usual practice in America con-

14 See Richard A. Posner, Economic Analysis of Law 627 (Aspen 5th ed 1998) (stating that "[t]he lawyer for the class will be tempted to offer to settle with the defendant for a small judgment and a large legal fee, and such an offer will be attractive to the defendant, provided the sum of the two figures is less than the defendant's net expected loss from going to trial").

15 See notes 135-37 and accompanying text.

16 See In re General Motors Corp Pick-Up Truck Fuel Tank Products Liability Litigation, 55 F3d 768, 784-85 (3d Cir 1995) (noting that "the law favors settlement" to conserve judicial resources, but that the interests of the absentee class members must be protected).

17 See Part IV for a discussion of this solution.

18 See James Wm. Moore, 10 Moore's Federal Practice $\$ 54.170$ at 54-245 to 46 (Matthew 
cerning attorneys' fees is that attorneys are paid according to contract with their clients. Win or lose, litigants bear their own expenses. This is known as the "American Rule." However, the rule has a number of exceptions. In these cases, courts may award attorneys' fees to a prevailing party. ${ }^{20}$ Two significant exceptions are statutory fee-shifting provisions and the equitable common fund doctrine. This Part explains the different rationales for these two exceptions to the American Rule, as well as the conflict of interest between attorneys and clients that may arise under the common fund doctrine but not under statutory fee shifting.

\section{A. Statutory Fee Shifting}

One exception to the American Rule is statutory fee shifting. Many federal statutes (over 150 as of $1995^{21}$ ), dealing with a host of topics, include fee-shifting provisions under which courts may order one party to pay another party's attorneys' fees. Many statutory feeshifting provisions explicitly require that only a successful or prevailing party may receive an award of fees, ${ }^{22}$ although not all do.

Bender 3d ed 2000) (contrasting the English and American Rules).

19 See Alyeska Pipeline Serv Co v Wilderness Society, 421 US 240, 247 (1975) (stating "[i]n the United States, the prevailing litigant is ordinarily not entitled to collect a reasonable attorneys' fee from the loser"); Herbert B. Newberg and Alba Conte, 3 Newberg on Class Actions $\S 14.01$ at 14-1 (McGraw-Hill 3d ed 1992) (stating that "[u]nder the American no-fee rule, a court may not award fees to a prevailing party unless expressly authorized by statute").

20 See Federal Judicial Center, Manual for Complex Litigation (Third) § 24.11 at 186-87 (West 1995). The manual lists five principal situations in which court-awarded attorneys' fees are appropriate: common fund cases (explained in Part I.A), statutory fee cases (explained in Part I.B), designated counsel (chosen by the court to perform certain tasks, such as lead counsel, for a group of litigants), special parties (the common law and many state statutes require courts to approve fees charged by counsel for minors, incompetents, and trusts), and sanctions (the common law, 28 USC $\$ 1927$ (1994), and FRCP 11 authorize courts to award fees against offending parties).

21 Federal Judicial Center, Manual for Complex Litigation \$24.11 at 186-87 (cited in note 20) (briefly discussing numerous statutes "ranging from antitrust and civil rights to little known types of claims").

22 See, for example, Truth in Lending Act, 15 USC § 1640(a)(3) (1994) (authorizing payment "in the case of any successful action" against a creditor for noncompliance with the Act, in the amount of "the costs of the action, together with a reasonable attorney's fee as determined by the court") (emphasis added); Magnuson-Moss Warranty-Federal Trade Commission Improvement Act, 15 USC $\$ 2310($ d)(2) (1994) (stating "[i]f a consumer finally prevails in any [product liability] action" under the Act, the court may award "the aggregate amount of cost and expenses (including attorneys' fees based on actual time expended) determined by the court to have been reasonably incurred ... unless the court in its discretion shall determine that such an award of attorneys' fees would be inappropriate") (emphasis added); Civil Rights Attorney's Fees Awards Act of 1976, 42 USC $\$ 1988$ (b) (1994) (stating "[i]n any action or proceeding to enforce a provision of sections 1981, 1981a, 1982, 1983, 1985, and 1986 of this title [and several other statutes] ... the court, in its discretion, may allow the prevailing party ... a reasonable attorney's fee as part of the costs") (emphasis added); Civil Rights Act of 1964, 42 USC $\S 2000 \mathrm{a}-3$ (b) (1994) (stating "[i]n any action commenced pursuant to this subchapter [prohibiting discrimination in places of public accommodation], the court, in its discretion, may allow the pre- 


\section{Purpose of statutory fee shifting.}

The main justification for statutory fee shifting is to provide an incentive for citizens to enforce certain laws as private attorneys gen$\mathrm{eral}^{24}$ even if they face limited resources. Justice Blackmun wrote that the rationale for fee-shifting provisions is "to strengthen the enforcement of selected federal laws by ensuring that private persons seeking to enforce those laws could retain competent counsel" even where potential plaintiffs lack resources to hire an attorney. ${ }^{25}$ The legislative history of fee-shifting provisions confirms this assertion. ${ }^{26}$

In cases featuring the possibility of significant monetary damages, indigent plaintiffs can overcome their lack of resources and attract competent attorneys through contingent fee arrangements. But if the potential relief is insignificant damages or an injunction, this is impos-

vailing party ... a reasonable attorney's fee as part of the costs") (emphasis added); Civil Rights Act of 1964, 42 USC $\$ 2000$ e-5(k) (1994) (substantially identical wording for subchapter prohibiting discrimination in employment); Fair Housing Act, 42 USC $\S 3612(\mathrm{p})$ (1994) (stating that in any case dealing with an alleged discriminatory housing practice, "the court ... in its discretion, may allow the prevailing party ... a reasonable attorney's fee and costs") (emphasis added).

23 Some statutes give courts broad discretion to award attorneys' fees to either side without an explicit determination of which side actually prevailed. See, for example, Securities Exchange Act of 1934, 15 USC $\$ 78 \mathrm{i}(\mathrm{e})$ (1994) (providing that in a suit under this Section, which authorizes suits for manipulation of security prices, "the court may, in its discretion, require an undertaking for the payment of the costs of such suit, and assess reasonable costs, including reasonable attorneys' fees, against either party litigant"); 15 USC $\$ 78 \mathrm{r}$ (a) (1994) (containing identical wording in section authorizing suits for misleading statements); Employee Retirement Income Security Act of 1974, 29 USC $\$ 1132(\mathrm{~g})(1)$ (1994) (stating "[i]n any action under this subchapter [which deals with the protection of employee benefit rights] ... by a participant, beneficiary, or fiduciary, the court in its discretion may allow a reasonable attorney's fee and costs of action to either party"); Clean Air Act, 42 USC § 7604(d) (1994) (stating "in issuing any final order" in a citizen suit to enforce various provisions of the Act, the court "may award costs of litigation (including reasonable attorney and expert witness fees) to any party, whenever the court determines such award is appropriate").

24 For a general discussion of the private law enforcement rationale, see John C. Coffee, Jr., Understanding the Plaintiff's Attorney: The Implications of Economic Theory for Private Enforcement of Law through Class and Derivative Actions, 86 Colum L Rev 669, 669 (1986) (arguing that enforcement through private attorneys general in American law "relies upon private litigants to enforce substantive provisions of law that in other legal systems are left largely to the discretion of public enforcement agencies").

25 City of Burlington v Dague, 505 US 557, 568 (1992) (Blackmun dissenting). See also Pennsylvania v Delaware Valley Citizens' Counsel for Clean Air, 483 US 711, 725 (1987) (agreeing that "a fundamental aim of such statutes is to make it possible for those who cannot pay a lawyer for his time and effort to obtain competent counsel, this by providing lawyers with reasonable fees to be paid by the losing defendants"); Brown v Phillips Petroleum Co, 838 F2d 451, 454 (10th Cir 1988) (noting that "statutory fees are intended to further a legislative purpose by punishing the nonprevailing party and encouraging private parties to enforce substantive statutory rights").

26 See Civil Rights Attorney's Fees Awards Act, S Rep No 94-1011, 94th Cong, 2d Sess 6 (1976), reprinted in 1976 USCCAN 5913 (explaining, in reference to the 1976 Act, that reasonable attorneys' fees are "adequate to attract competent counsel, but ... do not produce windfalls to attorneys"). 
sible. In such cases, statutory fee shifting serves an important function, providing an incentive for law enforcement. ${ }^{27}$

\section{Circumstances in which fee shifting is appropriate.}

Most fee-shifting statutes explicitly require that, to be eligible for an award of attorneys' fees, a party must have "succeeded" or "prevailed." Some lack this explicit requirement, instead allowing the court to award fees to, for example, "either party." whether a fee-shifting statute explicitly uses the word "prevail," it does not allow a court to shift fees to a losing party. ${ }^{30}$ Thus, courts have implied a "prevailing party" requirement into all fee-shifting statutes, regardless of their specific wording.

The definition of "prevailing party" is unclear and has been the subject of significant litigation. If a plaintiff wins a judgment on at least some of the merits of his claims (as opposed to a purely procedural or technical victory), he will be considered a prevailing party. ${ }^{31}$ The trickier question is deciding whether he has prevailed if he has settled his claims or entered into a consent decree; or, even if the litigation has reached no such formal legal conclusion, the defendant may voluntarily change his conduct towards the plaintiff, mooting the case.

The Supreme Court's latest pronouncement on the issue is Farrar $v$ Hobby. ${ }^{32}$ There, the Court established a relatively vague test for prevailing party status: "[A] plaintiff 'prevails' when actual relief on the merits of his claim materially alters the legal relationship between the parties by modifying the defendant's behavior in a way that directly benefits the plaintiff." the defendant's behavior in favor of the plaintiff, since they forced the

27 See, for example, id at 2, reprinted in 1976 USCCAN 5909-10 (explaining that the "purpose and effect" of the Civil Rights Attorney's Fees Awards Act of 1976 is "to allow courts to provide the familiar remedy of reasonable counsel fees to prevailing parties in suits to enforce the civil rights acts .... [The acts] depend heavily upon private enforcement, and fee awards have proved an essential remedy if private citizens are to have a meaningful opportunity to vindicate the important Congressional policies which these laws contain.").

28 See statutes cited in note 22. See also Moore, 10 Moore's Federal Practice $\$ 54.170$ at 54-245 to 46 (cited in note 18) (noting that fee-shifting statutes require the "loser" to pay the prevailing party's attorneys' fees).

29 Securities Exchange Act of 1934, 15 USC $\$ 78 \mathrm{i}(\mathrm{e})$. See note 23.

30 See Ruckelshaus $v$ Sierra Club, 463 US 680, 683-94 (1983) (holding that although the provision in question of Clean Air Act, 42 USC $\$ 7607(\mathrm{f})$, authorized fees in "appropriate" cases rather than requiring a party to have prevailed, it did not allow a court to shift fees to a plaintiff who lost on the merits of all claims).

31 See Hewitt v Helms, 482 US 755, 760 (1987) (requiring at least "some relief" on the merits of a claim for prevailing party status).

32506 US 103 (1992).

33 Id at 111-12. 
defendant to pay money that he otherwise would not pay, so the plaintiff was a prevailing party. ${ }^{34}$ However, it declined to award any attorneys' fees because the plaintiff had recovered an insignificant amount (nominal damages of one dollar after requesting seventeen million dollars in compensatory damages).

Farrar was a case that reached a jury verdict, but the Court noted that final judgment was not necessary for prevailing party status: "The plaintiff must obtain an enforceable judgment against the defendant ... or comparable relief through a consent decree or settlement. ${ }^{36}$ In an earlier case, Maher $v$ Gagne, the Court held that a civil rights plaintiff who entered into a settlement and consent decree was a prevailing party even though the case did not reach judgment. ${ }^{38}$

Thus, it is possible for a plaintiff to be considered the prevailing party even after settling rather than trying his case. However, in Maher the consent decree afforded the plaintiff "substantially all" of the relief originally sought. ${ }^{39}$ In contrast, settlements may fail to confer prevailing party status on the plaintiff if the defendant has agreed to settle purely because of the nuisance value of the suit. ${ }^{40}$ Compared to a judgment, a settlement is less certain to confer prevailing party status on the plaintiff.

Besides judgment or settlement, a final scenario in which the plaintiff may obtain prevailing party status (and therefore trigger statutory fee shifting) occurs if his suit is the "catalyst" for unilateral action by the defendant that moots the suit. ${ }^{41}$ However, to be considered prevailing, the plaintiff must prove that his suit actually caused the defendant's favorable action, and this can be difficult to show. This is a significant obstacle to prevailing party status under the catalyst theory. In addition, the catalyst theory may not survive much longer. Farrar cast doubt on the theory when it stated that to be con-

$34 \quad$ Id at 113.

35 Id at 114-16.

36 Id at 111 .

37448 US 122 (1980).

38 Id at 129 (stating "[ $t$ ]he fact that respondent prevailed through a settlement rather than through litigation does not weaken her claim to fees").

39 Id at 127.

40 See Texas State Teachers Association v Garland Independent School District, 489 US 782 , 792 (1989) (noting that prevailing party status may be denied "[w]here the plaintiff's success on a legal claim can be characterized as purely technical or de minimis"), citing Chicano Police Officer's Association v Stover, 624 F2d 127, 131 (10th Cir 1980) (stating that "[n]uisance settlements, of course, should not give rise to a 'prevailing' plaintiff').

41 See Hewitt, 482 US at 760-61 (stating that if the suit generates "a change in conduct that redresses the plaintiff's grievances ... the plaintiff is deemed to have prevailed despite the absence of a formal judgment in his favor"), citing Maher, 448 US at 129.

42 See, for example, Hooper v Demco, Inc, 37 F3d 287, 293 (7th Cir 1994) (holding that plaintiff did not prevail because defendant's action was gratuitous); Craig v Gregg County, 988 F2d 18, 21 (5th Cir 1993) (holding that plaintiff failed to show causation). 
sidered prevailing, the plaintiff must obtain a judgment or comparable consent decree or settlement. ${ }^{43}$ This statement can be read to exclude the catalyst theory as an additional means of gaining prevailing party status. It generated a circuit split, ${ }^{44}$ and the Supreme Court has granted certiorari on the issue.

To summarize, if a party wins a judgment on the merits, she has prevailed and the fee-shifting provision is activated. If a party settles, it is less clear that she has prevailed, and the fee-shifting provision may or may not operate, depending on the relief the settlement provides. Finally, if the defendant unilaterally changes its conduct, the plaintiff must meet the causation requirement of the catalyst theory in order to obtain prevailing party status; and the continuing validity of the catalyst theory is doubtful. In short, the only way to ensure prevailing party status, and thus to ensure the operation of a fee-shifting statute, is to win a final judgment on the merits.

\section{B. The Common Fund Doctrine}

Another exception to the American Rule is the common fund doctrine. The doctrine allows a court to distribute attorneys' fees from the common fund that is created for the satisfaction of class members' claims when a class action reaches settlement or judgment. ${ }^{46}$

Unlike fee shifting, which is authorized by statute, the common fund doctrine is a traditional equitable practice. ${ }^{47}$ In addition, its rationale differs from that of fee shifting. ${ }^{48}$ The doctrine is grounded in the principles of quantum meruit and unjust enrichment, in two senses. First, the doctrine prevents unjust enrichment of absent members of the class at the expense of the attorneys. It is meant to compensate the attorneys in proportion to the benefit they have obtained

43506 US at 111.

44 Compare Morris v City of West Palm Beach, 194 F3d 1203, 1206-07 (11th Cir 1999) (holding that the catalyst test remains valid after Farrar), with $S-1$ and $S-2 v$ State Board of Education, $21 \mathrm{~F} 3 \mathrm{~d}$ 49, 51 (4th Cir 1994) (en banc) (determining that the catalyst test is no longer viable).

45 See Buckhannon Board and Care Home, Inc $v$ West Virginia Department of Health and Human Resources, 121 S Ct 28 (2000).

46 See Sprague v Ticonic National Bank, 307 US 161,164 (1939) (holding that the authority to award fees from the common fund stems from the "historic equity jurisdiction of the federal courts"); Central Railroad \& Banking Co of Georgia v Pettus, 113 US 116, 124 (1885) (allowing payment from the common fund of "all expenses properly incurred in the preparation and conduct of the suit, including ... reasonable attorney's fees"); Trustees of the Internal Improvement Fund v Greenough, 105 US 527, 533 (1881) (same).

47 See Skelton v General Motors Corp, 860 F2d 250, 252 (7th Cir 1988) (collecting precedent and stating "when a case results in the creation of a common fund for the benefit of a plaintiff class, a court will exercise its equitable powers to award plaintiffs' attorneys' fees out of the fund").

48 See Lynk, 23 J Legal Stud at 186 \& n 3 (cited in note 5) (describing the "novelty" of the common fund doctrine and differentiating it from fee shifting). 
for the entire class (the fund), not just the representative members with whom they have contracted. ${ }^{49}$ Under the doctrine, the amount of the attorneys' compensation often depends on the size of the fund. ${ }^{30}$

Second, the doctrine prevents the unjust enrichment of absent class members at the expense of the class representatives. ${ }^{51}$ In the absence of the doctrine, only the present members, who hired the attorneys, would have to pay attorneys' fees, while all the members, both absent and present, would enjoy the benefits of the settlement or judgment. The members who did not hire the attorneys would be unjustly enriched at the expense of those who did.

\section{Conflicts of Interest under the Common Fund Doctrine and Statutory Fee Shifting}

An important difference between the two exceptions discussed above is who pays the attorneys. Under statutory fee shifting the loser pays the fees, while under the common fund doctrine the victorious class pays them. This generates a corresponding difference in the relief that the winners ultimately receive. Under fee shifting, the court awards fees in addition to whatever primary relief it grants the plaintiffs, and the amount of fees does not change the amount or type of the plaintiffs' relief. In contrast, under the common fund doctrine, as fees are subtracted from the fund, the amount available to satisfy class members' claims diminishes. The size of the fees therefore affects the size of the class members' relief. ${ }^{52}$

49 See Lindy Bros Builders, Inc of Philadelphia v American Radiator \& Standard Sanitary Corp, $487 \mathrm{~F} 2 \mathrm{~d} 161,165$ (3d Cir 1973) (holding the attorney entitled to funds under the equitable fund doctrine because he "conferred a benefit on all the class members, [one or more of whom] agreed by contract to pay for the benefit the attorney conferred upon him, and that the remaining class members should pay what the court determines to be the reasonable value of the services benefiting them").

50 The connection between the size of the fund and the size of the fees is especially apparent if the percentage method, explained in Part II.B, is used to calculate the fee, but can also be seen in the use of multipliers to enhance the lodestar (explained in Part II.A).

51 See Brytus v Spang \& Co, 203 F3d 238, 242 (3d Cir 2000) (stating "[t]he doctrine ... 'rests on the perception that persons who obtain the benefit of a lawsuit without contributing to its cost are unjustly enriched at the successful litigant's expense'"), quoting Boeing Co $v$ Van Gemert, 444 US 472, 478 (1980); Lindy, 487 F2d at 165 (noting that the class representative can claim "that by instituting the suit he has performed a service benefiting other class members. The reasonable value of that service is measured by the expenses incurred by the plaintiff on behalf of the class.").

52 See Court Awarded Attorney Fees: Report of the Third Circuit Task Force, 108 FRD 237, 255 (3rd Cir 1985):

[w] hen a class action lawyer secures a recovery for his clients and then proceeds to file a fee petition seeking compensation from those very same funds ... the plaintiffs' attorney's role changes from one of a fiduciary for the clients to that of a claimant against the fund created for the clients' benefit. 
Thus, payment of attorneys' fees under the common fund doctrine presents a conflict of interest between attorneys and clients that statutory fee shifting does not generate. ${ }^{53}$ This is an age-old conflict, but courts have tolerated it to avoid unjust enrichment of class members at the expense of the one filing suit. ${ }^{54}$ Under fee shifting, the plaintiffs' attorney remains the advocate of his clients and an adversary of the defendant throughout the trial, including the fee-setting phase. But under the common fund doctrine, the defendant is indifferent to the distribution of the fund as long as the fund discharges all of its obligations. So the adversarial relationship between the plaintiffs' attorney and the defendant disappears. Instead, the plaintiffs' attorney and the plaintiffs are left to fight over the division of the fund. This necessitates special care on the part of courts allocating common funds.

\section{MEthods of FeE CAlCUlation}

This Part explains the methods courts use to calculate fees. ${ }^{56}$ The primary method for calculating fees under statutory provisions is the lodestar, explained in Section A. Courts applying the common fund doctrine use either the lodestar or the percentage-of-the-fund method to calculate fees, but more frequently employ the percentage method, as described in Section B.

53 See id (noting that the conflict of interest that arises in the common fund context does not "arise in the statutory fee context, which continues to be an adversary proceeding until resolution").

54 See note 51.

55 See In re The Prudential Insurance Co of America Sales Practices Litigation, 148 F3d 283 (3d Cir 1998), which observed:

[A] thorough judicial review of fee applications is required in all class action settlements. When parties are negotiating settlements, the court must always be mindful of the danger ... that the lawyers might urge a class settlement at a low figure or on a less-than-optimal basis in exchange for red-carpet treatment for fees.

Id at 333. But see Susan P. Koniak and George M. Cohen, Under Cloak of Settlement, 82 Va L Rev 1051, 1089 (1996) (arguing that the fairness hearings courts conduct before approving settlements do "not appear adequate to prevent [abuse by lawyers]").

56 For a general discussion of fee awards under fee-shifting provisions and the common fund doctrine, see Alexander, 47 DePaul L Rev at 347 (cited in note 1) (discussing in particular awards in mass tort litigation); Stanley M. Grossman, Statutory Fee Shifting in Civil Rights Class Actions: Incentive or Liability?, 39 Ariz L Rev 587, 590-91 (1997) (discussing differences between fee-shifting and common fund calculations); Judith Resnick, Dennis E. Curtis, and Deborah R. Hensler, Individuals within the Aggregate: Relationships, Representation, and Fees, 71 NYU L Rev 296, 339-45 (1996) (same); Keith N. Hylton, Fee Shifting and Incentives to Comply with the Law, 46 Vand L Rev 1069, 1103-06 (1993) (same). 


\section{A. Statutory Fee Shifting: The Lodestar}

Courts determine a "reasonable" fee under fee-shifting provisions by the lodestar method, ${ }^{57}$ originally developed by the Third Circuit. $^{\text {s8 }}$ To calculate the prevailing counsel's lodestar, a court multiplies the amount of time reasonably expended on the litigation by a reasonable hourly rate, ${ }^{s 9}$ usually the prevailing market rate in the relevant community. ${ }^{60}$ The Supreme Court has endorsed the lodestar as the "guiding light of our fee-shifting jurisprudence."

\section{Presumption against multipliers.}

In developing the lodestar method, the Third Circuit envisioned that courts could increase or decrease the lodestar according to a number of factors, including the risk of loss and the quality of the attorney's work. ${ }^{62}$ Shortly afterward, the Fifth Circuit elaborated twelve factors $^{63}$ to be used in setting reasonable fees, which are sometimes referred to as the Johnson factors.

57 See Hensley $v$ Eckerhart, 461 US 424, 433 (1983) (explaining, in a case under 42 USC $\S 1988$, that " $[t]$ he most useful starting point for determining the amount of a reasonable fee is the number of hours reasonably expended on the litigation multiplied by a reasonable hourly rate. This calculation provides an objective basis on which to make an initial estimate of the value of a lawyer's services.").

58 See Lindy Bros Builders, Inc of Philadelphia v American Radiator \& Standard Sanitary Corp, 487 F2d 161, 167-69 (3d Cir 1973) (emphasizing the importance of deciding "the amount to which attorneys would be entitled on the basis of an hourly rate of compensation applied to the hours worked. This figure provides the only reasonably objective basis for valuing an attorney's services.").

59 See Hensley, 461 US at 433 (explaining that courts should begin the fee setting by multiplying "the number of hours reasonably expended on the litigation ... by a reasonable hourly rate").

60 See Blum v Stenson, 465 US 886, 895 (1984) (stating that "[ $t$ ]he statute and legislative history establish that 'reasonable fees' under $\S 1988$ are to be calculated according to the prevailing market rates in the relevant community").

61 City of Burlington v Dague, 505 US 557, 562 (1992) (holding contingency enhancement of attorneys' fees is not permitted under "typical" federal fee-shifting statutes).

62 See Lindy, 487 F2d at 168 (holding that the district court should consider "the contingent nature of success" and "the quality of an attorney's work ... consider[ing] the complexity and novelty of the issues presented, the quality of the work that the judge has been able to observe, and the amount of the recovery obtained").

63 See Johnson v Georgia Highway Express, Inc, 488 F2d 714, 717-19 (5th Cir 1974) (enumerating factors).

64 The twelve factors are:

1) the time and labor required;2) the novelty and difficulty of the questions involved;3) the skill requisite to perform the legal services properly; 4) the preclusion of other employment by the attorney due to acceptance of the case; 5) the customary fee; 6 ) whether the fee is fixed or contingent; 7) time limitations imposed by the client or other circumstances; 8 ) the amount involved and the results obtained;9) the experience, reputation, and ability of the attorneys; 10) the "undesirability" of the case; 11) the nature and length of the professional relationship with the client; and 12) awards in similar cases. 
However, the Supreme Court has strictly limited the use of these upward adjustments, also known as multipliers, in the context of statutory fee shifting. In Blum v Stenson, ${ }^{65}$ the Court established a strong presumption that the unenhanced lodestar is the reasonable statutory fee. Attorneys from the Legal Aid Society of New York brought a civil rights challenge to the termination of Medicaid benefits on behalf of a statewide class of recipients. . $^{6}$ After winning summary judgment, the attorneys applied for fees under the Civil Rights Attorney's Fees Awards Act of $1976 .^{67}$ They requested a total of $\$ 118,968$, consisting of the lodestar amount of $\$ 79,312$ (for 809 hours of work at rates of $\$ 95$ to $\$ 105$ per hour) plus an upward adjustment of fifty percent to reflect the novelty and complexity of the issues, the quality of representation, the great benefit obtained for the large class, and the risk of nonpayment. ${ }^{68}$ The Court held that attorneys applying for fees carry the burden of proving that upward adjustments are necessary to determine a reasonable fee, and that in this case the attorneys had not supplied the required proof. ${ }^{69}$ The Court noted that lodestar enhancements could be justified "in some cases of exceptional success," so it did not rule out the possibility, but it made clear that district courts should not hand them out liberally.

\section{Risk multipliers impermissible.}

One type of multiplier that has attracted the attention of the Supreme Court is the risk multiplier, by which a court would increase the lodestar to compensate for the possibility of losing the case and therefore not recovering any fees. In Blum, the majority explicitly declined to decide whether multipliers for the risk of loss are ever permissible."

In a concurrence, Justice Brennan, joined by Justice Marshall, argued that they should be allowed on the basis of the legislative history of the statute at issue. ${ }^{2}$ First, although the legislative history did not explicitly mention risk multipliers, it cited cases employing risk multi-

Johnson, $488 \mathrm{~F} 2 \mathrm{~d}$ at 714.

65465 US 886 (1984).

66 Id at 889-90 (providing background on the suit and on the attorneys representing the Medicaid recipients).

6742 USC \& 1988.

68 Blum, 465 US at 890-91.

69 Id at 898-99 (referring to the plaintiffs' attorney's brief as "conclusory" and going on to state that complexity and novelty of the issues are both inappropriate factors to consider in setting the fee award).

70 Id at 897, quoting Hensley $v$ Eckerhart, 461 US 424, 435 (1983).

71 See 465 US at 901 n 17 (observing that the Court had "no occasion" to consider the issue in the case at bar).

72 See id at 902-04 (Brennan concurring) (citing Congress's citation of cases supporting use of upward adjustment for the risk of loss). 
pliers as examples of the correct calculation of reasonable fees. ${ }^{73}$ Second, if a reasonable rate is supposed to reflect the prevailing market rate and therefore enable poor plaintiffs "to attract competent counsel," ${ }^{\text {,4 }}$ risk multipliers should be allowed, since lawyers working in the marketplace "can be expected to charge a higher hourly rate when their compensation is contingent on success than when they will be promptly paid, irrespective of whether they win or lose.,"75

The Court finally reached the question of risk multipliers in City of Burlington $v$ Dague ${ }^{76}$ and held that they are impermissible when calculating the lodestar under a statutory fee-shifting provision. ${ }^{n}$ The Court gave five reasons for its position.

First, using risk multipliers is "double counting" because the lodestar without enhancement already accounts for the risk of losing a case, "either in the higher number of hours expended to overcome the difficulty, or in the higher hourly rate of the attorney skilled and experienced enough to do so.",78

Second, although risk multipliers would increase the incentives to pursue meritorious claims, they would also indiscriminately raise the incentives to bring meritless claims. ${ }^{79}$

Third, risk multipliers contradict the language of fee-shifting statutes that award attorney's fees only to successful or prevailing parties. Awarding a risk multiplier "would in effect pay for the attorney's time ... in cases where his client does not prevail.",

Fourth, risk multipliers are consistent with the percentage model but not the lodestar model: attorneys using the percentage method in the market (by contracting with their clients for contingent fees) account for risk when setting those fees (and adjust the contract per-

73 See id at 902-03, citing S Rep No 94-1011 at 6 (cited in note 26).

74 S Rep No 94-1011 at 6 (cited in note 26). See also Civil Rights Attorney's Fees Awards Act of 1976, HR Rep No 94-1558, 94th Cong, 2d Sess 9 (1976).

75 Blum, 465 US at 903 (Brennan concurring) (noting that such an approach is also "entirely consistent with the market-based approach to hourly rates").

76505 US 557 (1992) (regarding fees for suit brought under the Solid Waste Disposal Act and Federal Water Pollution Control Act).

77 Id at 567 (reversing a court of appeals award of a lodestar enhancement of 25 percent).

78 Id at 562.

79 Id at 563 (giving a mathematical example to show that result).

80 Id at 565. Judge Posner has made a similar argument:

The fundamental problem of a risk bonus is that it compensates attorneys, indirectly but effectively, for bringing unsuccessful civil rights suits, even though the attorney's fee statute is expressly limited to cases where the party seeking the fee prevails... Suppose a plaintiff asks for and receives a multiplier of 2 because he had a 50 percent chance of losing the case. This means that if the plaintiff's lawyer tries 10 such cases and wins 5 (as one would expect, if the risk of loss is indeed $\mathbf{5 0}$ percent), he will be paid as if he had won them all; that is, he will be paid twice his normal charge for each of the 5 cases he won, to compensate him for getting nothing in the 5 cases he lost. 
centage accordingly). ${ }^{81}$ Therefore, the Court concluded, risk enhancements are a feature of the percentage method; and since the Court has generally turned away from the percentage method and toward the lodestar method, ${ }^{82}$ it should not "engraft this feature onto the lodestar model" and "concoct a hybrid scheme that resorts to the contingentfee model to increase a fee award but not to reduce it."

Finally, risk multipliers would increase the complexity of setting fee awards and therefore would increase the possibility of "burdensome satellite litigation" over fees.

\section{B. Calculating Fees in Common Fund Cases}

An attorney whose work creates a common fund is "entitled to a reasonable fee ... taken from the fund." ${ }^{, 85}$ Unlike in the fee-shifting context, where the lodestar controls, there are two possible methods for calculating fees under the common fund doctrine.

\section{Percentage or lodestar?}

Traditionally, courts awarding fees from common funds employed the percentage method, ${ }^{86}$ under which the attorneys receive simply a percentage of the fund that constitutes a "reasonable" fee." The awards usually range from 20 to 30 percent of the fund, and some

81 See Dague, 505 US at 566 (stating that "attorneys factor in the particular risks of a case in negotiating their fee and in deciding whether to accept the case").

82 See id at 565-66 (citing earlier decisions and stating that the Court has made this shift "even though the lodestar model often (perhaps generally) results in a larger fee award").

83 Id at 566 (going on to state that contingency enhancement is inconsistent with the Court's "general rejection of the contingent-fee model for fee awards" and is unnecessary "to the determination of a reasonable fee"). The prohibition on court awarded risk multipliers to the lodestar does not mean that attorneys cannot contract with their clients for fees in excess of the lodestar. See Venegas $v$ Mitchell, 495 US 82, 86-87 (1990) (holding, in a nonclass action feeshifting case under 42 USC $\$ 1988$, that the statute did not prohibit contingent fee contract under which the prevailing plaintiff agreed to pay his attorney more than the statutory amount).

84 Dague, 505 US at 566 (stating that "[c]ontingency enhancement would make the setting of fees more complex and arbitrary, hence more unpredictable, and hence more litigable").

85 Goldberger v Integrated Resources, Inc, 209 F3d 43, 47 (2d Cir 2000) (referring to this principle as the "salient exception" to the general rule that litigants must pay their own expenses). See also Boeing Co v Van Gemert, 444 US 472, 478 (1980) (noting that common fund cases are the exception to the general rule that litigants pay their own expenses and citing numerous court opinions to support this proposition).

86 See Goldberger, 209 F3d at 48 (stating that "[f]or much of the 20th century, the percentage approach prevailed").

87 See Paul, Johnson, Alson \& Hunt v Graulty, 886 F2d 268, 272 (9th Cir 1989) (determining under the specific facts of the case that it would be "impractical, if not impossible" to determine the number of hours worked by the attorneys, as required under the lodestar method).

88 See In re Washington Public Power Supply System Securities Litigation, 19 F3d 1291, 1297 (9th Cir 1994) (noting that the district court "acknowledged Class Counsel's central proposition that a fee in the range of $20-40$ percent is typical in many common fund cases"); Swedish Hospital Corp $v$ Shalala, 1 F3d 1261, 1272 (DC Cir 1993) (stating "[t]he twenty percent figure is 
courts have adopted benchmarks in this range, such as 25 percent, for setting fees.

In the 1970 s, many courts began to view the percentage method as problematic because it generated windfalls for attorneys in cases with exceptionally large funds. Some courts avoided this problem by reducing the percentage awarded. However, this exposed the method to criticism as unprincipled. ${ }^{90}$

In response to these criticisms, the Third Circuit developed the lodestar method in 1973 , $^{97}$ initiating a general movement toward it." As they did under fee-shifting provisions before Blum and Dague, courts under the common fund doctrine have enhanced the lodestar by subjective factors such as "the risk of the litigation and the performance of the attorneys." $"$

The lodestar method turned out to be more difficult to apply than first envisioned. In 1985, a Third Circuit task force evaluated the lodestar method and listed nine problems that judges and practitioners had experienced with it: ${ }^{24}$ (1) calculating the lodestar was a time- and effort-intensive process that increased the workload of the courts and sapped resources;" (2) the lodestar calculation was "insufficiently objective" and produced widely inconsistent results; ${ }^{96}$ (3) the calculation created a false "sense of mathematical precision that is unwarranted

well within the range of reasonable fees in common fund cases. .. A majority of common fund class action fee awards fall between twenty and thirty percent").

89 See, for example, Paul, $886 \mathrm{~F} 2 \mathrm{~d}$ at 272 (adopting 25 percent as a benchmark). See also Federal Judicial Center, Manual for Complex Litigation $\$ 24.121$ at 189 (cited in note 20) (citing range of 25 to 30 percent and collecting examples).

90 The percentage is set using the "same 'less objective' factors that are used to determine the multiplier for the lodestar." Goldberger, 209 F3d at 47, quoting Brown v Phillips Petroleum Co, 838 F2d 451, 454-55 (10th Cir 1988).

91 See Lindy Bros Builders, Inc of Philadelphia v American Radiator \& Standard Sanitary Corp, 487 F2d 161, 167 (3d Cir 1973) (holding that "an hourly rate of compensation applied to the hours worked ... provides the only reasonably objective basis for valuing an attorney's services"). See Part II.A for discussion of the lodestar and its origin.

92 See, for example, City of Detroit v Grinnell Corp, 495 F2d 448, 469, 471 (2d Cir 1974) (noting that the percentage approach often produces an improper "golden harvest of fees" and holding that only the lodestar method was sufficiently objective to be legitimate).

93 Goldberger, 209 F3d at 47.

94 See Court Awarded Attorneys Fees: Report of the Third Circuit Task Force, 108 FRD 237, 246 (3d Cir 1985). As commentators have noted, the credibility of the lodestar is severely undermined because the circuit that promulgated its use has now become its leading critic. See, for example, Coffee, 86 Colum L Rev at 675 (cited in note 24) (stating "[e]ven the Third Circuit, which originally authored the 'lodestar' fee award formula that now prevails in federal courts, reexamined its own invention in 1985 and found it seriously deficient and subject to abuse").

95 See Court Awarded Attorney Fees, 108 FRD at 246 (stating that "[t]he increased documentation demanded ... the practice of conducting fee hearings ... and the desire to avoid misfeasance have so magnified the process that the system's human and physical resources are being deflected from other, perhaps more important, duties").

96 Id at 246-47 (stating that this problem led to a loss of predictability and "loss of confidence in the integrity of the fee-setting procedure"). 
in terms of the realities of the practice of law";" (4) judges manipulated the lodestar calculation by first deciding the percentage or dollar amount to be awarded and then adjusting the multipliers to reach the desired result; ${ }^{98}(5)$ attorneys abused the lodestar system by "running the meter," working unnecessary hours and inflating billing rates;" (6) attorneys also abused the lodestar system by prolonging litigation in order to increase billable hours; ${ }^{100}$ (7) the calculation did not provide flexibility in needed areas, such as rewarding lawyers for early settlement; ${ }^{101}$ (8) the public interest bar, especially civil rights lawyers, felt that lodestars in cases producing monetary recovery were systematically set higher than in cases generating nonmonetary relief, ${ }^{102}$ and (9) the lodestar method involved many administrative difficulties, such as which community courts should consider in determining the normal billing rate an attorney commands. ${ }^{1.3}$

While the task force disclaimed the ability to evaluate the empirical strength of these criticisms, ${ }^{104}$ it recommended that the lodestar be used in statutory fee cases but that the percentage method be used in common fund cases. ${ }^{105}$ The task force recommended this because the lodestar (to be used in statutory fee cases) "is reasonably objective, neutral, and does not require making monetary assessments of intangible rights that are not easily equated with dollars and cents," but these protections were unnecessary in the common fund context be-

97 Id at 247 (noting, for example, that many plaintiffs' attorneys work through contingent fee arrangements and therefore have no actual customary billing rate to be used in the calculation).

98 Id (noting that "Lindy [which set forth the lodestar method] is subject to manipulation by judges who prefer to calibrate fees in terms of percentages of the settlement fund or the amounts recovered by the plaintiffs or of an overall dollar amount").

99 Id at 247-48 (stating "Lindy encourages lawyers to expend excessive hours ... engage in duplicative and unjustified work, inflate their 'normal' billing rate, and include fictitious hours or hours already billed on other matters, perhaps in the hope of offsetting any hours the court may disallow").

100 Id at 248 (stating that "Lindy creates a disincentive for the early settlement of cases... [and a] desire to keep the litigation alive despite a reasonable prospect of settlement, to maximize the number of hours to be included in computing the lodestar").

101 Id (finding that the "preoccupation with the lodestar computation deprives the trial court of much needed discretion to take proper account of the variousness of litigation," but also noting that greater discretion would contribute to concerns about the lack of uniformity and "contribute to the concerns of the public interest bar").

102 Id at $248-49$ (stating that "[ $t$ ]he claim is that lodestars in the so-called 'money' cases, such as securities and antitrust actions, are set higher than they are in cases under statutes promoting nonmonetary social objectives, such as the Civil Rights Attorney's Fees Awards Act of 1976").

103 Id at 249 (questioning whether the rate should be national or local, and if local, whether "the forum's rate or each petitioning attorney's local rate" should be used).

104 Id at 246 (but also acknowledging a "widespread belief that the deficiencies ... either offset or exceed its benefits").

105 Id at 255. 
cause the fund was usually sizeable. ${ }^{106}$ Since then, the percentage method has made a comeback. The Eleventh and D.C. Circuits have gone so far as to mandate use of the percentage method in common fund cases.

Of the other circuit courts that have addressed the choice between the methods, only the Fifth Circuit mandates the lodestar ${ }^{108}$ (with an upward or downward adjustment depending on the Johnson twelve-factor analysis ${ }^{109}$ ). The rest have left the choice to the discretion of the district courts, ${ }^{110}$ but several of these incline toward the percentage approach. " For example, the Tenth Circuit has held that "either method is permissible," but there is a "preference for the percentage of the fund method."

106 Id.

107 See Swedish Hospital Corp, 1 F3d at 1272 (stating "we conclude that percentage-of-thefund is the proper method for calculating fees in a common fund case"); Camden I Condominium Association, Inc v Dunkle, 946 F2d 768, 774 (11th Cir 1991) ("[W]e believe that the percentage of the fund approach is the better reasoned in a common fund case.").

108 See Longden $v$ Sunderman, 979 F2d 1095, 1099-1100 \& n 9 (5th Cir 1992) (stating that "[t]his circuit utilizes the "lodestar method," and noting that the Fifth Circuit "has yet to adopt" the percentage approach in common fund cases).

109 See Johnson v Georgia Highway Express, Inc, 488 F2d 714, 717-19 (5th Cir 1974) (listing the factors and reminding courts they "do not have a mandate ... to make the prevailing counsel rich"); Lyn-Lea Travel Corp v American Airlines, Inc, 2000 US Dist LEXIS 14487, *31-32 (N D Tex) (applying the Johnson factors and determining that none required an adjustment in the lodestar).

110 See, for example, Weinberger $v$ Great Northern Nekoosa Corp, 925 F2d 518, 526 n 10 (1st Cir 1991) (commenting on the "tendency exhibited by some courts, particularly in common fund cases, to jettison the lodestar in favor of a 'reasonable percent of the fund' approach," but finding it inappropriate for the specific facts of the case); Mazola v May Department Stores Co, 1999 WL $1261312, * 3-4$ (D Mass) (applying the percentage approach); Goldberger, 209 F3d at 49 (collecting decisions of six other circuits that have "reaffirmed that district courts enjoy the discretion to use either the lodestar or the percentage method" in common fund cases; adopting this position with the caveat that courts should avoid "unwarranted windfalls for attorneys"); In re Agent Orange Product Liability Litigation, 818 F2d 226, 237 (2d Cir 1987) (noting that district courts are "given broad discretion" in setting fee awards); Rawlings v Prudential-Bache Properties, Inc, 9 F3d 513, 515-16 (6th Cir 1993) (citing the "recent trend towards adoption of a percentage of the fund method" in common fund cases and listing cases adopting the approach); Cook v Niedert, 142 F3d 1004, 1010 (7th Cir 1998) (asserting that "a district judge has discretion to use either [the lodestar or percentage] method, depending on the particular circumstances of the case"); Cashman v Allied Products Corp, 761 F2d 1250, 1255-56 (8th Cir 1985) (noting that a district court has significant discretion in fixing a reasonable fee); Washington Public Power, 19 F3d at 1296 (noting that in common fund cases there is no presumption in favor of either method, that the district court has discretion to choose between them, and that the fundamental guiding principle is that fees be reasonable under the circumstances); Florida v Dunne, 915 F2d 542, 545 (9th Cir 1990) (requiring "only that fee awards in common fund cases be reasonable under the circumstances. Accordingly, either the lodestar or the percentage-of-the-fund approach" may be used.).

111 See In re General Motors Corp Pick-Up Truck Fuel Tank Products Liability Litigation, 55 F3d 768, 821 (3d Cir 1995) (stating that, while courts may use the lodestar method in some nonstatutory fee cases, they "must vigilantly guard against the lodestar's potential to exacerbate the misalignment of the attorneys' and the class's interests").

112 Gottlieb v Barry, 43 F3d 474, 483 (10th Cir 1994). 
trict courts, the district courts employ the percentage method more frequently than the lodestar. ${ }^{113}$

\section{Lodestar multipliers in pure common fund cases.}

Most courts have concluded that applying risk multipliers to the lodestar in pure common fund cases is appropriate after Dague. ${ }^{114} \mathrm{~A}$ few courts, however, have refused to apply risk multipliers in common fund cases. ${ }^{115}$ The majority approach best reconciles the text of the feeshifting statutes, the purpose of the common fund doctrine, and the policy arguments offered in Dague itself.

Even though there is no applicable fee-shifting statute in a pure common fund case, at first cut, some of the Dague Court's reasons for prohibiting risk multipliers might seem to apply with equal strength in the common fund context. Inclusion of a risk factor might lead to double counting because risk should already be reflected in the hourly rate and/or number of hours spent on the case. ${ }^{16}$ Risk multipliers might encourage excessive unmeritorious suits, as well as satellite litigation over fees."

On the other hand, not all of the Dague reasons for the prohibition on risk multipliers extend to lodestar fee awards from common

113 See Brytus v Spang \& Co, 203 F3d 238, 243 (3d Cir 2000) (stating "[a]ttorney's fees under the common fund doctrine may be calculated using the lodestar method but more frequently such fees have been awarded using the percentage-of-recovery method").

114 See In re The Prudential Insurance Co of America Sales Practices Litigation, 148 F3d 283, 341 n 121 (3d Cir 1998) (dictum) (but noting that "[even if] multipliers for risk or counsel's expertise are appropriate in the lodestar cross-check in common fund cases, they require particular scrutiny and justification"); Longden v Sunderman, 979 F2d 1095, 1099 (5th Cir 1992) (stating that despite trends in other circuits, the Fifth Circuit uses the lodestar method "computed by multiplying the number of hours reasonably expended by the prevailing hourly rate in the community for similar work"); Rawlings v Prudential-Bache Properties, Inc, 9 F3d 513, 517 (6th Cir 1993) (upholding district court decision using the "lodestar-multiplier method"); Cook v Niedert, 142 F3d 1004, 1013 (7th Cir 1998) (allocating discretion to district court to select multiplier in decision using lodestar method); Florin v Nationsbank of Georgia, N.A., 34 F3d 560, 564-65 (7th Cir 1994) (concluding Dague "applies only to statutory fee-shifting cases" by its terms and because the policy concerns that weigh against risk multipliers in statutory fee-shifting cases do not apply to common fund cases); Washington Public Power Supply System Securities Litigation, 19 F3d 1291, 1299 (9th Cir 1994) (stating "Dague's rationale for barring risk multipliers in statutory fee cases does not operate to bar risk multipliers in common fund cases").

115 See In re Nineteen Appeals Arising Out of the San Juan Dupont Plaza Hotel Fire Litigation, 982 F2d 603, 620 (1st Cir 1992) (Lay concurring) (stating that "[a]s Dague makes clear, use of the lodestar method ... should not include a multiplier for contingency reasons"); In re General Motors Corp Pick-Up Truck Fuel Tank Products Liability Litigation, 55 F3d 768, 822 (3d Cir 1995) (stating in dictum that courts cannot use risk multipliers in the common fund context after Dague).

116 See Dague, 505 US at 562-63.

117 See id at 563, 566. But see Peter-Christian Olivo, Comment, No More Times Tables: Risk Multipliers in Attorneys' Fee Awards after In Re Bolar Pharmaceutical Co, 77 Minn L Rev 893, 913-17 (1993) (arguing that risk multipliers should be allowed because omitting them undercompensates attorneys for taking risky cases). 
funds. First, in a pure common fund case there is no relevant statutory language requiring that only successful plaintiffs be compensated, so at least the payment for work on unsuccessful cases as well as successful ones does not actually violate a statute (even if it does encourage some undesirable unmeritorious litigation). ${ }^{118}$ Second, the Dague Court rejected the use of risk multipliers in the fee-shifting context only. Courts have not abandoned the percentage method in common fund cases, so even if risk multipliers are a feature of the percentage method, using them in the common fund context would not be improper (as opposed to the fee-shifting context, where courts employ the lodestar exclusively).

Finally, beyond the Dague arguments, the purposes of statutory fee shifting and the common fund doctrine differ. Fee shifting, according to the legislative history, exists simply to eliminate the bias in favor of clients with the means to pay; so it should be limited to the market value of the work an attorney has expended on a case, independent of the size of the clients' recovery. The common fund doctrine is meant to compensate attorneys proportionately to the benefit they have conferred on their clients; so it should depend on the size of the clients' recovery. The vast majority of courts have reached the correct conclusion.

Despite the increased popularity of the percentage of the fund approach, the application of Dague's ban on risk multipliers in the common fund context is an important issue. Even when courts award fees under the percentage method, they often crosscheck their result using an enhanced lodestar.

The percentage method often generates much higher fees than the unenhanced lodestar. ${ }^{119}$ However, courts have enabled high percentage awards to survive the lodestar crosscheck by adjusting the lodestar with multipliers to about the same award that the percentage method produces. If risk multipliers are inappropriate in the common fund context, rationalizing percentage awards with lodestar crosschecks could become much more difficult.

In summary, while risk multipliers to the lodestar are inappropriate in the fee-shifting context after Dague, they may be appropriate in the common fund context. We now turn to the problem this Comment addresses: how to meet the demands of a fee-shifting statute and also satisfy the requirements of the common fund doctrine.

118 See Part I.B for a discussion of the equitable basis of the common fund doctrine.

119 See Brytus v Spang \& Co, 203 F3d 238, 247 (3d Cir 2000) (noting that in some cases the percentage method may result in a higher recovery than the lodestar (this is logical, especially if the class's award is huge)). But see Dague, 505 US at 566 (stating that "the lodestar model often (perhaps, generally) results in a larger fee award" than the percentage method because it may cause lawyers to run up hours unnecessarily). 


\section{The SeTtlement InCENTIVe Problem In Hybrid CASES}

How should fees be calculated in hybrid cases (class actions initiated under fee-shifting statutes, but settling or reaching judgment to create a common fund)? Should the statute or the equitable doctrine control? Can the rules be structured to give attorneys appropriate incentives to pursue settlement aggressively without compromising their clients' interests? To understand the improper incentives that might be created under the current system, it is useful to compare how attorneys' fees in a hybrid case are affected by the two possible scenarios: (1) settling the case; or (2) litigating it to judgment.

\section{A. Hybrid Cases That Settle, Creating a Common Fund}

When a hybrid case settles, the fee-shifting provision is not necessarily activated, since neither party may have prevailed in a legal sense. ${ }^{120}$ The defendant creates a common fund in exchange for release from liability, leaving the court in charge of distributing it. Under the common fund doctrine, district courts in the majority of the circuits have discretion over the method of calculation, while the Fifth Circuit requires the lodestar and the Eleventh and D.C. Circuits mandate the percentage method. ${ }^{121}$ However, since a majority of courts still employ lodestar multipliers in the common fund context, the percentage and lodestar methods result in approximately the same fees.

\section{B. Hybrid Cases That Reach Judgment, Creating a Common Fund}

When the class in a hybrid case actually wins a judgment, it is unclear whether the court should award fees under the fee-shifting statute (lodestar without multipliers) or the common fund doctrine (percentage of recovery or, basically equivalent, lodestar with multipliers)

120 There is some possibility that a court might award statutory fees to one of the settling parties if the court considers one of the parties to have substantially prevailed. See Part I.A.2. See also Da-Wai Hu, Comment, Running the Caucus-Race: Prevailing Parties and Fee Shifting Under ERISA, 67 U Chi L Rev 217, 226-29 (2000) (explaining how settling plaintiffs can sometimes be considered prevailing parties for purposes of the ERISA fee-shifting provision). In these cases, fees could theoretically be awarded under the statute instead of, or in addition to, the fees awarded under the common fund doctrine. This would remove the disproportionate incentive to settle (because either settling or trying the case could lead to statutory fees), but then attorneys would discriminate against bringing hybrid cases in favor of pure common fund cases. See Part III.B.

121 See Part II.B.

122 See Newberg and Conte, 3 Newberg on Class Actions $\S 14.03$ at 14-4-5 (cited in note 19) (noting that "[c]ourts applying the lodestar approach [in the common fund context] will often use large multipliers or monetary enhancements of the time/rate (lodestar) calculation in order to reach fee award results comparable to percentage of recovery fees. Multiples ranging from one to four frequently are awarded in common fund cases" and even greater multiples may be employed if the fund is especially large.). 
or both. The primary reason for this uncertainty is a striking paucity of cases involving both common funds and fee-shifting statutes that have actually resulted in a judgment on the merits. Although at first pass that might suggest that the proper method of calculation is a relatively unimportant and obscure point of law, it is also entirely consistent with the argument that uncertainty over the ability of courts to supplement attorneys' fees out of the common fund in hybrid cases has resulted in too many settlements.

Currently, the Third Circuit is the only federal appellate court that has addressed the issue of how attorneys' fees are calculated in a hybrid class action. In Brytus $v$ Spang \& $\mathrm{Co}^{123}$ attorneys won a $\$ 12,500,000$ judgment on behalf of a class of retirees against their former employer, which had violated ERISA by failing to distribute to them surplus assets of a pension plan. ${ }^{124}$ The plaintiffs sought attorneys' fees under the fee-shifting provision of ERISA, ${ }^{125}$ and the plaintiffs' attorneys also requested fees from the common fund. ${ }^{126}$ Since the plaintiffs had clearly prevailed and therefore fee shifting was appropriate, the district court had two options: award fees under the statute only (unenhanced lodestar), or under both the statute and the common fund doctrine (percentage or enhanced lodestar).

The district court ordered the defendant to pay $\$ 460,000$ in fees under the statute, but declined to award anything from the common fund because it "believed counsel had already been reasonably compensated." ${ }^{127}$ The attorneys contested this award in the Third Circuit, arguing that they should have been entitled to total fees in the range of $\$ 3,000,000$ under the common fund doctrine (calculating a 20 to 30 percent fee). ${ }^{128}$

The Third Circuit held that the district court had not abused its discretion in limiting the award to the lodestar under the fee-shifting statute. $^{129}$ However, the court noted that the availability of a feeshifting provision did not totally foreclose use of the common fund doctrine in a hybrid case that reaches a judgment. ${ }^{130}$ It explained that

123203 F3d 238 (3d Cir 2000).

124 Id at $240-41$.

12529 USC $\$ 1132(\mathrm{~g})(1)$.

126 Brytus, 203 F3d at 241 (explaining counsel's fee proposal).

127 Id at 243, 245 (going on to dismiss counsel's contention that the trial court believed it lacked the authority to grant the full fee request). The trial court version of Brytus resulted only in a slip opinion. See In re Spang \& Co Litigation, Nos 88-1548, 91-1041, slip op at 2 (W D Pa July 14, 1997).

128 Brytus, $203 \mathrm{~F} 3 \mathrm{~d}$ at 241,243 (noting the attorneys' assertion that the district court should have awarded the lodestar under the statute, plus the percentage of the fund minus the lodestar award, so as to avoid double compensation).

129 Id at 247 (stating "the District Court here did not abuse its discretion in declining to award additional fees to be taken from the ERISA recovery under the common fund doctrine").

130 Id (stating that " $\mathrm{t}]$ his is not to say that the common fund doctrine may never be applied 
additional fees might be drawn from the fund if the defendant is insolvent, or if the plaintiffs' attorneys show that the plaintiffs could not have obtained competent counsel in the private market for the lodestar amount.

Limiting the common fund doctrine to extraordinary circumstances in hybrid cases, as the Brytus court did, could cause a significant problem: a disproportionate incentive to settle class actions, regardless of the best interests of the plaintiff class. The attorneys in Brytus raised this argument, ${ }^{132}$ and the court answered it by suggesting that district courts administering hybrid case settlements should crosscheck the percentage calculation with the lodestar to ensure that the fee is reasonable. ${ }^{133}$ But this solution seems flawed. When calculating the lodestar under the common fund doctrine (against which to crosscheck the percentage fee), a majority of courts use multipliers, ${ }^{1.4}$ which they cannot use in the simple fee-shifting context. The lodestar with multipliers is likely to be much closer to the percentage fee than the unenhanced lodestar. Thus, crosschecking the percentage with the enhanced lodestar will probably not produce many reductions in the fees drawn from settlement funds under the common fund doctrine.

As the dissent in Brytus recognized, the possibility of a percentage award at settlement but a "substantially smaller" lodestar award at judgment "creates a compelling incentive for the plaintiffs' counsel to settle." ${ }^{135}$ Agency problems already plague class actions. ${ }^{136}$ The in-

in a case for which there is a statutory fee provision and which goes to judgment").

131 Id (noting in dicta that the common fund doctrine could be applied "when the defendant responsible for the statutory fee has become bankrupt or otherwise has insufficient funds[,] ... when there has been a showing that competent counsel could not have been obtained for that case or that line of cases," or in "other possible situations").

132 See id at 246 (noting the attorneys' argument "that the District Court penalized them for proceeding to judgment, which resulted in the award of a statutory fee, whereas they would have been entitled to a fee under the common fund doctrine had they accepted a settlement").

133 Id at 247 (saying the disparity "will be minimized" if these steps are taken).

134 See notes 114-15 and accompanying text.

135203 F3d at 248-49 (Stapleton dissenting) (expressing concern "about the practical implications" of the majority's opinion).

136 See id at 249 (noting that the incentive to settle increases "the already significant conflict of interest between plaintiff class members and their counsel"). See also Ortiz v Fibreboard Corp, 527 US 815, 851-53 (1999) (noting pressures to settle class actions after certification); Janet Cooper Alexander, Do the Merits Matter? A Study of Settlements in Securities Class Actions, 43 Stan L Rev 497, 536 (1991) (noting that class actions "are characterized by high agency costs: that is, a significant possibility that litigation decisions will be made in accordance with the lawyer's economic interests rather than those of the class"); Jonathan R. Macey and Geoffrey P. Miller, The Plaintiffs' Attorney's Role in Class Action and Derivative Litigation: Economic Analysis and Recommendations for Reform, 58 U Chi L Rev 1, 19-27 (1991) (discussing monitoring, incentive, and other agency costs that arise in class action and derivative litigation); Coffee, 86 Colum $\mathrm{L}$ Rev at 714 (cited in note 24) (stating "[o]ften, the plaintiff's attorneys and the defendants can settle on a basis that is adverse to the interests of the plaintiffs. At its worst, the settlement process may amount to a covert exchange of a cheap settlement for a high award of attorney's fees."). 
credible amount of work required to try a massive, complicated class action provides a huge incentive to settle before judgment in any event. If actually winning a judgment for the plaintiff class lowers the likelihood of a common fund award, so that only the least lucrative option (the unenhanced lodestar) remains, the agency problems are exacerbated. ${ }^{137}$ Attorneys' self-interest may persist over their clients' interests, resulting in few class actions that actually reach judgment. It seems fair to infer that the reason there has been so little discussion of this problem in judicial opinions is the lack of opportunities for judges to write opinions confronting the problem, as plaintiffs' attorneys settle in their own best interests at the expense of the classes they purport to represent.

It is true that settlements are generally desirable because they avoid expensive litigation and because the parties can presumably fix their own solution better than the judicial system could through a trial. ${ }^{138}$ However, the desire of plaintiffs' attorneys to obtain higher fees at the expense of their clients is not a legitimate reason to increase the rate of settlements further, especially considering the already significant reasons why plaintiffs' attorneys may wish to settle class actions quickly. Neither is it a legitimate reason to decrease the amount of recovery for which plaintiffs' attorneys are willing to settle.

\section{A Solution to the Settlement InCEntive Problem}

This Part considers four possible solutions to the settlement incentive problem of Brytus. Any solution to the skewed incentive problem must equalize the potential results of settlement and judgment ${ }^{140}$ and remain faithful to the purpose of the fee-shifting statutes, which is to attract competent counsel for meritorious claims. ${ }^{141}$ There are four possible ways to equalize the expected results of judgment to match

137 In circuits where the percentage method is mandatory (D.C. and Eleventh) for common fund fee awards, the incentive to settle is even greater than in most circuits (where courts can choose between percentage and lodestar with multipliers) because settling guarantees the percentage method, which may be slightly more predictable than the lodestar with multipliers.

138 See In re General Motors Corp Pick-Up Fuel Tank Products Liability Litigation, 55 F3d 768,784 (3d Cir 1995) (noting that "the law favors settlements" to conserve judicial resources). But see Alexander, 43 Stan L Rev at 499 (cited in note 136) (arguing that "a significant and identifiable class of settlements [in securities class actions] is in reality neither voluntary nor accurate ... in that the strength of the case on the merits has little or nothing to do with determining the amount of the settlement").

139 See note 14 and accompanying text.

140 See Brytus, 203 F3d at 249 (Stapleton dissenting) (reasoning that "the method of awarding attorneys' fees should not turn on the manner in which the case is resolved"). Some disincentive to try class actions would still exist, because of the time and effort required for a trial, but at least the disincentive would not be artificially intensified.

141 See notes 25-26. 
those of settlement: (1) construe any settlement as evidence that the plaintiff class has "prevailed" or "succeeded," thus triggering the relevant fee-shifting statute; (2) crosscheck the percentage fee at settlement with the unenhanced lodestar and reduce the percentage to match the lodestar; (3) allow risk multipliers to increase the lodestar under fee-shifting statutes in hybrid cases; or (4) establish a presumption that recovery from the common fund is warranted along with the statutory lodestar amount (this option would run contrary to Brytus, which established the opposite presumption). As explained below, the presumption in favor of recovery from the common fund best reconciles the purpose of fee-shifting statutes and the class action device.

\section{A. Courts Should Not Extend Fee-Shifting Statutes to the Settlement Context}

One possible solution is to treat all settling plaintiffs as "prevailing" or "successful," so that whether a hybrid case is settled or tried, the fee-shifting statute controls. But there are several reasons why courts should not adopt this possible solution. First, automatically construing all settlements as evidence that the plaintiff class has prevailed for purposes of statutory fee shifting would generate factually incorrect results. It would be an overbroad rule, sweeping in cases in which the plaintiff has not achieved her objectives in bringing suit. For example, the settlement of a nuisance suit does not justify giving the plaintiff prevailing party status. ${ }^{142}$ Since a plaintiff who settles has not necessarily achieved her original objectives in the litigation, it should not automatically show that she has prevailed.

Second, this solution would limit the recovery at settlement to the unenhanced lodestar, equalizing the expected values of settlement and judgment at the lower (judgment) level and representing a return to the unenhanced lodestar across the board. In many cases, this would reduce attorneys' incentive to bring cases governed by fee-shifting statutes as class actions; instead, attorneys would prefer to pursue claims on behalf of individual clients.

For example, if an employer had improperly withheld benefits from a large number of employees, bringing the claims separately would allow attorneys to earn the lodestar for work on an individual case many times over. Bringing all the claims together as a class action would generate a larger lodestar than the lodestar in an individual case because of the greater time required to prepare a class action. However, in many cases it would be smaller than the individual lodestar multiplied by the number of plaintiffs (especially if this number 
were huge), because of economies of scale. Therefore, awarding the unenhanced lodestar at both settlement and judgment would discourage the aggregation of plaintiffs into classes in cases governed by feeshifting statutes.

It might be argued that discouraging aggregation is beneficial, because in setting the fee-shifting recovery at a specific level (the unenhanced lodestar), Congress intended to encourage a specific amount of litigation under statutes with fee-shifting provisions. On this view, recovery should be limited to the congressionally specified level because any increase would generate more litigation than Congress wished to enable. But the Supreme Court has held (outside the class action context) that nothing in 42 USC $\S 1988$ or its legislative history prohibits a lawyer from collecting a fee higher than the statutory amount. ${ }^{1.3}$ So the statutory amount sets a minimum rather than a maximum fee.

Thus, it is unlikely that Congress intended to enable a calibrated amount of litigation through statutory fee shifting. However, assuming that is true, the class action device does not necessarily enable more plaintiffs to recover than Congress contemplated. In many situations, class actions enable litigation when many people would each be entitled to a small recovery, none of which would individually be worth an attorney's labor. ${ }^{144}$ Absent the class action device, none of these plaintiffs at all would be able to take advantage of the fee-shifting statutes.

In addition, even if class actions allow somewhat more recovery than Congress intended, the benefits of the class action device likely exceed the costs of excess recovery. Aggregation of claims produces great judicial economy gains by resolving all of a defendant's liabilities in a single action and eliminating multiple trials on the same issues. Discouraging the aggregation of claims into class actions forgoes these judicial economy gains on the basis of dubious congressional intent. In summary, this potential solution suffers from a number of problems, and courts should not adopt it.

143 See Venegas $v$ Mitchell, 495 US 82,86-87 (1990) (stating that "there is nothing in [ $\$ 1988$ ] to regulate what plaintiffs may or may not promise to pay their attorneys if they lose or if they win," that $\$ 1988$ does not prohibit "the plaintiff from promising an attorney a percentage of any money judgment that may be recovered," and that nothing "in the legislative history ... persuades us that Congress intended $\S 1988$ to limit civil rights plaintiffs' freedom to contract [for contingent fees] with their attorneys").

144 See Amchem Products, Inc v Windsor, 521 US 591, 617 (1997) (discussing how class actions overcome these collective action problems).

145 See General Telephone Co of the Southwest v Falcon, 457 US 147, 159 (1982) (reversing a class certification because it "did not advance the efficiency and economy of litigation which is a principal purpose of the procedure") (internal quotations omitted). 


\section{B. Courts Should Not Reduce Percentage Fees at Settlement to Match the Unenhanced Lodestar}

This solution would produce the same effect as the first solution. It would equalize fees at settlement and judgment at the level of the unenhanced lodestar. It would also generate the same basic problem: a disincentive to aggregate claims into class actions, based on a doubtful congressional "intent" to cap fees at the statutory amount. ${ }^{146}$ Thus, courts should not adopt it.

\section{Courts Should Not Allow Risk Multipliers to Enhance the Lodestar in Hybrid Cases}

The third possibility, allowing risk multipliers in calculating the lodestar under the statutory provision (in hybrid cases only, not in simple fee-shifting statutory cases), has the advantage of preserving the plaintiffs' attorney's dedication to his clients and adversarial relationship with the defendant throughout the trial, including the feesetting phase.

Despite this significant advantage, there are serious objections to this option. First, it would contradict Dague's explicit rejection of risk multipliers in the statutory fee-shifting context. ${ }^{147}$ Second, it would contradict the language of many fee-shifting provisions, which prohibit courts from effectively compensating attorneys for work on cases in which they did not prevail. ${ }^{14}$

Dague might be distinguishable because it was not a class action. It is arguable that the preservation of the plaintiff class-attorney relationship is significant enough to override the disadvantages of risk multipliers with which the Dague Court was concerned. However, this argument does nothing to confront the fact that allowing risk multipliers would contradict the plain language of fee-shifting statutory provisions. Thus, courts should not adopt this possible solution.

\section{Courts Should Create a Presumption of Ordinary Percentage Recovery}

The best option is to establish a presumption that fees totaling an ordinary percentage recovery ( 20 to 30 percent of the fund) should be awarded under both the fee-shifting provision and the common fund doctrine, with money from the fund making up the difference between the statutory unenhanced lodestar and the 20 or 30 percent bench- 
mark. ${ }^{149}$ The presumption could be defeated if the fund were extraordinarily large, and thus generated enormous fees.

Two problems with this solution are that it turns the plaintiffs' attorney into the plaintiffs' adversary during fee-setting and that it increases the potential for excessive fees. But these problems are no worse than those courts encounter during the settlement of hybrid cases, so they should be manageable. A third possible objection is that this solution could skew attorneys' incentives to pursue statutory feeshifting claims as class actions rather than as individual actions. However, this justifies the solution rather than defeating it. As indicated in Part IV.A, class actions save judicial resources. Also, the argument that class actions permit more recovery than Congress intended is weak. ${ }^{150}$

In addition, the purposes of statutory fee shifting and the common fund doctrine support the idea that fee-shifting provisions should not preempt additional equitable awards. Fee-shifting provisions exist to ensure that attorneys are compensated with at least the lodestar amount, eliminating the bias against taking the cases of poor plaintiffs. ${ }^{\text {ts1 }}$ These provisions should be taken as setting a minimum fee. Under the common fund doctrine the attorney is additionally entitled to a reward proportionate to the benefit obtained for the class. As a matter of equity, there is no reason why the attorney's fees should be limited to the statutory lodestar minimum if the benefit conferred on the plaintiffs exceeds that minimum. Overall, establishing a presumption of fee availability under both the statute and the common fund doctrine is probably a better way to equalize settlement and judgment fee potential, and to remove extra incentives to avoid judgment, than is the allowance of risk multipliers. ${ }^{152}$ Finally, presuming a full percentage fee in hybrid cases, regardless of whether they are settled or tried, would remove any incentive attorneys may have to discriminate against hybrid cases. ${ }^{153}$

149 This was the award requested by the attorneys in Brytus. See 203 F3d at 243-44 (explaining the attorneys' fee request and argument that "since the result of the litigation was to create a common pension fund for the benefit of all plaintiff class members, they are entitled to additional fees based on the common fund doctrine").

150 See Part IV.A.

151 See notes 25-26.

152 There is a possibility that in a similar future case, if the anti-Brytus presumption has not been established, attorneys who have learned from Brytus will simply not invoke the fee-shifting provision (in order to avoid being limited to it). This would force the court to apply the equitable doctrine alone; but the court could reduce the equitably awarded fee by the unenhanced lodestar, thus requiring the attorneys to request fees under the statute in order to recover the full benchmark percentage amount.

153 See Part III.B. 


\section{CONCLUSION}

The current interpretation of the boundary between statutory fee-shifting provisions and the common fund doctrine established in Brytus skews plaintiffs' attorneys' incentives unacceptably toward settlement rather than trial in hybrid cases. Courts should instead establish a presumption that the percentage calculation provides the benchmark for recovery in hybrid cases. Although strong settlement incentives would remain, the percentage approach would not aggravate them excessively, as the Brytus lodestar presumption does. 